\title{
EFEKTIVITAS SISTEM PENGENDALIAN INTERN PADA KINERJA INSTANSI PEMERINTAH DI DINAS PENDAPATAN DAERAH KABUPATEN MINAHASA SELATAN
}

\author{
Victor Youbert Stenly Suak ${ }^{1}$, Jenny Morasa ${ }^{2}$, Sintje Rondonuwu $^{3}$ \\ 1,2,3 Jurusan Akuntansi, Fakultas Ekonomi dan Bisnis, Universitas Sam Ratulangi, Jl. Kampus Bahu, Manado, \\ 95115, Indonesia \\ E-mail : victor.suak@gmail.com
}

\begin{abstract}
In a government organization requires the existence of an internal control system because with the existence of an internal control system, activities carried out by government agencies are more directed and avoid fraud and safe guard the company's assets from irresponsible parties. The object in this study is the Regional Revenue Service of South Minahasa Regency. The purpose of this study is to analyze the effectiveness of the internal control system on the performance of government agencies in the Regional Revenue Service of South Minahasa Regency. The research method used is descriptive qualitative. Results of research internal control systems applied Government Institution in Regional tax and Retribution Management Agency of South Minahasa Regency are less effective. The achievement of Revenues and realization of Regions in 2016 is less effective because the regional Tax and Retribution Management Agency was only formed in early 2016.
\end{abstract}

Keywords: Effectiveness, Internal Control

\section{PENDAHULUAN}

Negara Kesatuan Republik Indonesia sudah mengalami perubahan, pertumbuhan dan perkembangan dalam bidang ekonomi dan bidang pemerintahan. Pemerintah harus berupaya untuk meningkatkan dan melakukan pemerataan pembangunan. Agar mencapai tujuan Negara Kesatuan Republik Indonesia yaitu masayarakat adil dan makmur berdasarkan Pancasila dan UUD 1945. Sebagai daerah otonomi, harus menggali potensi pendapatan daerah yang sah karena itu instansi pemerintah harus memiliki suatu tanggungjawab agar dapat memperhatikan kesejahteraan rakyat dan memelihara ketentraman serta keamanan rakyat Indonesia. Maka dari itu harus diperlukan suatu sistem agar dapat memberikan keyakinan yang memadai supaya kegiatan yang diselenggarakan di instansi pemerintah agar dapat dicapai suatu tujuan yang efektif serta efisien, dan harus dilaporkan pengelolaan keuangan negara yang handal, mendorong ketaatan terhadap peraturan perundang-undangan dan mengamankan aset dari negara.

Sistem yang dimaksud adalah Sistem Pengendalian Intern yang diterapkan agar diperhatikan suatu rasa keadilan dan kepatutan dengan mempertimbangkan kompleksitas, ukuran, serta fungsi dan tugas instansi pemerintah. Dalam Unsur Sistem Pengendalian Intern dalam Peraturan Pemerintah harus berpedoman dalam Sistem Pengendalian Intern yang sudah dipraktikkan di ruang lingkup pemerintahan di berbagai negara, adalah :

1. Lingkungan pengendalian, seorang pemimpin instansi dan semua pegawai instansi pemerintah agar memelihara serta menciptakan suatu lingkungan di suatu organisasi agar dapat menimbulkan suatu tindakan yang positif serta mendukung pengendalian intern juga manajemen yang sehat.

2. Penilaian risiko, untuk dapat mengendalikan internal control ada baiknya memberikan suatu nilai-nilai atas suatu risiko yang nantinya akan dihadapi suatu organisasi, baik dari luar maupun dari dalam. 
3. Kegiatan pengendalian, Untuk memastikan suatu proses pemberian bimbingan dan pengarahan baik dari pemimpin suatu intansi maupun dari pemerintah harus dilakukan dengan baik. Dalam penerapan kegiatan pengendalian, haruslah efektif dan efisien untuk pencapaian suatu tujuan organisasi.

4. Informasi dan komunikasi dalam laporan atau pun dalam pencatatan untuk pemimpin suatu Instansi Pemerintah atau pihak-pihak lainnya, yang telah ditentukan. Informasi harus disediakan dalam bentuk atau sarana, sehingga waktu yang tepat dapat memungkinkan bagi pimpinan sebuah Instansi untuk pelaksanaan tanggung jawabnya.

5. Pemantauan di nilai dari sebuah kualitas kinerja dalam rentan waktu untuk memastikan bahwa pengauditan serta reviu, akan dapat ditindak lanjuti.

Alasan mengapa penulis mengambil objek pada Dinas Pendapatan Daerah karena dalam Dinas Pendapatan Daerah Kabupaten Minahasa Selatan harus melaksanakan sistem pengendalian internal pada kinerja Dinas Pendapatan Daerah Kabupaten Minahasa Selatan. Didalam Dinas Pendapatan Daerah Kabupaten Minahasa Selatan, pengendalian internal sangat penting diperlukan, Karena dengan adanya pengendalian internal maka kegiatan yang dilakukan oleh instansi pemerintah lebih terarah dan terhindar dari kecurangan dan menjaga harta perusahaan dari pihak-pihak yang tidak bertanggung jawab, maka judul penelitian ini "Efektivitas Sistem Pengendalian Intern Pada Kinerja Instansi Pemerintah di Dinas Pendapatan Daerah Kabupaten Minahasa Selatan".

\section{TINJAUAN PUSTAKA}

Akuntansi. Pengertian Akuntansi merupakan aktivitas jasa yang meliputi, pencatatan, mengklasifikasikan, dan pelaporan suatu kejadian ataupun transaksi yang akhirnya bakal menghasilkan informasi keuangan yang bakal dierlukan bagi pihak-pihak tertentu dalam pengambilan keputusan (Sujarweni, $2015: 1$ ).

Akuntansi Sektor Publik. Pengertian dari Akuntansi sektor publik bisa diartikan sebagai aktivitas jasa yang meliputi, pencatatan, menghasilkan, dan pelaporan suatu kejadian atau transaksi yang akhirnya bakal menghasilkan informasi keuangan yang bakal dibutuhkan oleh pihak-pihaktertentu dalam pengambilan keputusan, yang telah diterapkan pada pengelolaan anggaran publik di badan-badan tinggi Negara dan departemen dibawahnya (Sujarweni 2015:12).

Sistem Pengendalian Intern. Penerapan Sistem Pengendalian Intern Pemerintah yang meliputi lingkungan pengendalian, penilaian risiko, aktifitas pengendalian, informasi dan komunikasi dan pengawasan tidak bisa dilepaskan dari peran serta manusia sebagai pelaku utama dalam menjalankan sistem itu. Indikator yang pertama, lingkungan pengendalian berkaitan dengan peran pimpinan dan staf SKPD untuk menciptakan organisasi yang memiliki komitmen terhadap kompetensi, gaya operasi dan filosofi manajemen serta kegiatan pengawasan yang dilakukan oleh Inspektorat/Bawasda melalui audit dan reviuatas kegiatan SKPD secara independen (Damayanti, 2015). Pengendalian internal adalah kebijakan dan prosedur yang diterapkan untuk memastikan keandalan yang berkelanjutan sistem akuntansi. Keakuratan dan keandalan adalah yang terpenting dalam dunia akuntansi. Tanpa catatan akuntansi yang akurat, manajer tidak dapat membuat keputusan keuangan sepenuhnya, dan laporan keuangan dapat mengandung kesalahan (Abdullahi, 2016). Tujuan pokok pengendalian intern dyange terdiri dari mengecek ketelitian dan keandalan akuntansi, mendorong efisiensi serta menjaga kekayaan organisasi (Mulyadi 2016:129).

Kinerja. Kinerja ialah sebuah gambaran atas sebuah kegiatan di mana telah mencapai tingkat sasarannya,baik visi misi bahkan strategi organisasi.Penggunaan arti kinerja di khususkan untuk mengetahui sebuah tingkatan suatu keberhasilan baik perorangan atau kelompok. Tidak ada tujaun atau target, sehingga kinerja dari individu atau kelompok tidak mempunyai tolak ukur yang jelas. (Mahsun, 2014:25). 
Konsep Pendapatan Asli Daerah. Pendapatan asli daerah adalah seluruh penerimaan yang bersumber dari pendapatan asli daerah. Pengelompokkan Pendapatan Asli Daerah teridiri dari, pajak daerah, retribusi daerah, kekayaan daerah yang dipisahkan, dan lain-lain PAD yang sah (Halim, 2013:101).

Efektivitas. Menurut Yonas Muanley (2016). Segi etimologi, Kata efektif yang di padanan kata dari bahasa Inggris yialah dari kata "effective". Pengertian dari kata ini adalah keberhasilan ataupun suatu yang telah dilakukan menjadi berhasil menjadi baik. Dalam Kamus Besar Bahasa Indonesia, efektifitas mempunyai pengertian di antaranya, akibatnya, kesan dan pengaruh, efektif, mampu membawa suatu hasil yang baik. Sedangkan di kamus Ilmiah terpopuler, efektivitas merupakan hasil guna, menunjang suatu tujuan dan ketepatgunaan. Pengertian efektivitas menurut Teori, sebagaimana yang telah dimaksud dalam kamus atas arti pasti sama dari setiap waktu. tapi tidak begitu serta dalam pengertian sesuatu kata dalam teori-teori tertentu.. Dapat dimaksudkan efektivitas adalah suatu konsep penggambaran akan suatu keberhasilan organisasi untuk mencapai suatu tujuan. Jadi pengertian efektifitas ialah proses pengukuran kesuksesan untuk mencapai suatu tujuan yang sudah ditetapkan atas pemakaian proses pemilihan cara dan aturan atas tujuan yang telah di sesuaikan.

$$
\text { Rasio Efektivitas }=\frac{\text { Realisasi Penerimaan PAD }}{\text { Target Penerimaan PAD }} \text { X100\% }
$$

Dengan mengetahui perbandingan antara realisasi penerimaan dengan target yang ditetapkan maka penilaian kriteria efektivitas dapat diukur berdasarkan Kepmendagri No. 690.900-327 tahun 1996 tentang pedoman penilaian dan kinerja keuangan yaitu:

Tabel 2.1

Kriteria kinerja keuangan (efektivitas)

\begin{tabular}{|c|c|}
\hline Tingkat Ketaatan Sampel & Kriteria Efektif \\
\hline $100 \%$ keatas & Sangat Efektif \\
\hline $90 \%-100 \%$ & Efektif \\
\hline $80 \%-90 \%$ & cukup Efektif \\
\hline $60 \%-80 \%$ & Kurang efektif \\
\hline Kurang dari $60 \%$ & Tidak efektif \\
\hline
\end{tabular}

Sumber: Depdagri, Kepmendagri No. 690.900-327 Tahun 1996

\section{METODE PENELITIAN}

Jenis Penelitian. Dalam penelitian ini penulis menggunakan penelitian deskriptif. Penelitian deskriptif ialah penelitian yang dilakukan supaya mengetahui nilai variabel mandiri, baik satu variabel atau lebih (independen) dan jangan melakukan perbandingan, serta menghubungkan beberapa variabel (Sugiyono, 2013:3). Melalui penelitian deskriptif ini penulis akan memberikan gambaran mengenai sistem pengendalian intern pemerintah yang terdiri dari, lingkungan pengendalian, penilaian resiko, kegiatan pengendalian, pemantauan, serta informasi dan komunikasi, atas kinerja instansi pemerintah di Dinas Pendapatan Daerah Kabupaten Minahasa Selatan.

Tempat dan Waktu Penelitian. Penelitian ini dilakukan pada Instansi Pemerintahan di Dinas Pendapatan Daerah Kabupaten Minahasa Selatan di Komplek Perkantoran Kabupaten Minahasa Selatan pada bulan September 2017 sampai November 2017. 


\section{Metode Pengumpulan data}

1. Jenis data. Dalam penelitian ini penulis menggunakan jenis data kualitatif. Data kualitatif yang dibutuhkan dalam penelitian ini adalah Sistem Pengendalian Intern Pemerintah dan penerimaan Dinas Pendapatan Daerah Kabupaten Minahasa Selatan.

2. Sumber data. Dalam penelitian penulis menggunakan sumber data sekunder. Data sekunder yang dibutuhkan ialah mengolah data serta didapat langsung dari Dinas Pendapatan Daerah Kabupaten Minahasa Selatan, dan data sekunder merupakan data yang diambil dari bahan pustaka.

Metode Analisis. Menurut Nazir (2014:43) "metode deskriptif adalah suatu metode dalam meneliti status sekelompok manusia, suatu objek, suatu set kondisi, suatu sistem pemikiran, ataupun suatu kelas peristiwa pada masa sekarang"

\section{HASIL PENELITIAN DAN PEMBAHASAN}

\subsection{Hasil Penelitian}

Dalam Pencapaian Kinerja Badan Pengelolaan Pajak dan Retribusi Daerah Kabupaten Minahasa Selatan tetap melaksanakan program dan kegiatan untuk menigkatkan pengelolaanpenerimaan daerah. Kinerja yang telah di capai dapat di lihat dalam rincian berikut:

Tabel 4.1

Target dan Realisasi Penerimaan Pendapatan Daerah Kabupaten Minahasa Selatan Tahun 2016

\begin{tabular}{|c|c|c|c|c|}
\hline No & Jenis penerimaan & Target (Rp) & Realisasi (Rp) & \% \\
\hline 1 & Pajak & $8,624,434,000$ & $8,557,355,454$ & 99.2 \\
\hline 2 & Retribusi & $5,231,012,000$ & $2,995,345,165$ & 57.2 \\
\hline 3 & Lain-Lain PAD yang SAH & $24,175,000,000$ & $18,538,006,995$ & 76.7 \\
\hline
\end{tabular}

Sumber : Badan Pengelolaan Pajak dan Retribusi Daerah Kabupaten Minahasa Selatan

Dari hasil Tabel 4.1 di atas diperoleh hasil target dan realisasi penerimaan pendapatan Daerah Kabupaten Minahasa Selatan 2016, dari segi pajak daerah, retribusi dan lain-lain PAD yang sah telah mencapai target yang ditetapkan pemerintah. Penerimaan pajak dari target yang ditetapkan yaitu sebesar Rp. 8.624.434.000 tidak tercapai dengan realisasi sebesar Rp. 8.557.355.454, sedangkan retribusi daerah dengan target Rp.5.231.012.000 tidak tercapai Rp. 2.995.345.165 dan lain-lain PAD yang sah dengan target Rp. 24,175,000,000 tidak tercapai Rp. 18,538,006,995. Jika ditotalkan keseluruhan penerimaan pendapatan daerah adalah target sebesar Rp. 38,030,446,000 dan realisasi sebesar Rp. 30.090.707.614 dengan presentase 79.1.

Penjabaran berdasarkan Hasil Wawancara objek penelitian menurut Peraturan Pemerintah No. 60 Tahun 2008 tentang Sistem Pengendalian Intern Pemerintah. Dijabarkan Oleh Ibu Nancy Ludong (Kepala Bidang Pajak dan Retribusi Daerah)

\section{Lingkungan Pengendalian}

- Memiliki potensi dan kemampuan,kewibawaan,kejujuran, Contoh: Penagihan Pajak

- Aturan yang harus dipahami oleh seluruh ASN di barengi dengan etika sehingga ASN (BPPRD) beretika baik dan berintegritas tinggi

- Sumber daya manusia harus ada

- Dapat bertanggung jawab dalam melaksanakan tugas

- Membangun komitmen dan kemopetensi dalam tugas dibidang pajak dan retribusi, Contoh: mengidentifikasi dan menetapkan besaran pajak kepada wajib pajak berdasarkan aturan.

- Permasalahan dapat di selesaikan dengan bijaksana

- Memerlukan keteladanan ketika menghadapi permasalahan yang terjadi 
- Agar bisa menjalankan tugas pokok serta fungsi secara efisien dan efektif

- Dasar aturan dalam Kabupaten Minahasa Selatan nomor 6 tahun 2016 tentang susunan dan pembentukan perangkat Daerah Kabupaten Minahasa Selatan.

- Tugas dan tanggungjawab yang diberikan atasan dapat dilaksanakan sesuai aturan dan sasaran.

- Melaksanakan rapat dinas dan mengikutsertakan dalam kegiatan Bimtek sesuai Tugas dan Fungsi.

- Melaksanakan pengawasan rutin dalam melaksanakan tugas administrasi dan tugas lapangan (pengawasan dan penagihan pajak kepada wajib pajak).

- Dalam melaksanakan tugas hanya bekoordinasi dengan instansi terkait dalam mencapai maksud dan tujuan yaitu dapat meningkatkan PAD.

\section{Penilaian Resiko}

- Dalam melaksanakan tugas terlebih dahulu mengadakan perencanaan kerja yang sesuai.

- Dalam setiap program pemerintah yang akan dilaksankan harus duduk bersama menyampaikan program dan menetapkan bersama untuk mencapai tujuan dan rencana instansi pemerintah agar tercapai dan berhasil alam pelaksanaannya.

\section{Kegiatan Pengendalian}

- Agar tidak terjadi monopoli fungsi dipisahkan sesuai TUPOKSI.

- Agar permasalahan dalam tugas terkontrol dan mendapatkan solusi sesuai kejadian.

- Membuat dokumentasi agar menjadi dasar penyelesaian atas kejadian penting,transaksi dan pengendalian intern.

\section{Informasi dan Komunikasi}

- Mampu mengetahui system informasi lewat internet.

\section{Pemantauan}

Agar dapat mengetahui segala sesuatu yang menjadi kendala dalam melaksanakan tugas dan dapat mencari solusi atau jawaban untuk diselesaikan secepatnya. Sebagai bahan evaluasi untuk menjadi acuan peningkatkan kinerja dalam melaksanakan tugas di tiap-tiap bidang.

\subsection{Pembahasan}

Dari hasil penelitian dapat diketahui bahwa jumlah penerimaan tahun 2016 kurang efektif karena target dari Badan Pengelolaan Pajak dan Retribusi Daerah Kabupaten Minahasa Selatan belum bisa dicapai dari yang direncanakan. Jadi sistem pengendalian intern pemerintah dalam pencapaian kinerja organisasi kurang efektif. Dengan adanya sistem pengendalian intern (internal control) yang kurang efektif maka Badan Pengelolaan Pajak dan Retribusi Daerah Kabupaten Minahasa Selatan harus lebih ditingkatkan dan dikembangkan kinerja instansi agar supaya di tahun berikutnya bisa mencapai hasil yang memuaskan atau sangat efektif.

Dan dari hasil pengolahan data, Badan Pengelolaan Pajak dan Retribusi Daerah Kabupaten Minahasa Selatan telah mengikuti dan menjalankan 5 unsur yang menggambarkan sejauh mana sistem pengendalian intern pemerintah atas kinerja di Badan Pengelolaan Pajak dan Retribusi Daerah Kabupaten Minahasa Selatan tapi harus ditingkatkan dan dikembangkan dengan berpedoman dengan UU No 60 tahun 2008.

\section{KESIMPULAN DAN SARAN}

\subsection{Kesimpulan}

Bersumber pada pada hasil penelitian serta pembahasan maka dapat disimpulkan antara lain sebagai berikut.

1. Sistem pengendalian intern yang diterapkan Instansi Pemerintahan di Badan Pengelolaan Pajak dan Retribusi Daerah Kabupaten Minahasa Selatan kurang efektif karena belum 
mencapai target sesuai dengan Sistem Pengendalian Intern Pemerintah yang telah ditetapkan oleh pemerintah berdasarkan Peraturan Pemerintah Nomor 60 Tahun 2008.

2. Pencapaian Penerimaan Pendapatan dan Realisasi daerah tahun 2016 kurang efektif karena Badan Pengelolaan Pajak dan Retribusi Daerah baru dibentuk pada awal tahun 2016.

3. Pemisahan tugas yang dilakukan Badan Pengelolaan Pajak dan Retribusi Daerah Kabupaten Minahasa Selatan, harus dperhatikan dan dikembangkan sehingga terhindar dari kecurangan dan agar supaya bisa dikatakan efektif.

\subsection{Saran}

Berdasarkan hasil kesimpulan yang dihasilkan dalam hasil penelitian serta pembahasan, maka dapat disarankan sebagai berikut :

1. Sistem pengendalian pemerintah yang telah ada di Badan Pengelolaan Pajak dan Retribusi Daerah Kabupaten Minahasa Selatan diharapkan untuk lebih meningkatkan dan mengembangkan agar efektivitas kinerja di Badan Pengelolaan Pajak dan Retribusi Daerah Kabupaten Minahasa Selatan bisa lebih efektif dan lebih maksimal di tahun berikut.

2. Badan Pengelolaan Pajak dan Retribusi Daerah Kabupaten Minahasa Selatan sangat diharapkan untuk terus meningkatkan efektifitas kerja dan harus memotivasi pegawai agar dapat memberikan kinerja yang baik dan berusaha memberikan hasil yang terbaik agar kinerja dari Badan Pengelolaan Pajak dan Retribusi Daerah Kabupaten Minahasa Selatan dapat mencapai target yang lebih efektif.

3. Badan Pengelolaan Pajak dan Retribusi Daerah Kabupaten Minahasa Selatan perlu lebih memperhatikan keluhan-keluhan dan masukan yang disampaikan dari masyarakat/warga terhadap kemajuan instansi.

4. Untuk peneliti selanjutnya, yang ingin melakukan penelitian tentang sistem pengendalian intern pemerintah agar memperbaharui literature dan undang-undang yang berhubung dengan sistem pengendalian intern pemerintah yang sewaktu-waktu diubah/direvisi menurut undang-undang yang ada.

\section{DAFTAR PUSTAKA}

Abdullahi H. Mohamed \& Muturi Willy. 2016. Effect Of Internal Control Systems On Financial Performance Of Higher Education Institutions In Puntland. International Journal Of Economics, Commerce And Management United Kingdom Vol. Iv, Issue 12, December 2016.

Damayanti, Indah Ayu 2015. Analisis efektivitas dan kontribusi penerimaan pajak bumi dan bangunan terhadap pendapatan asli daerah di kota Denpasar. E-Jurnal Akuntansi Universitas Udayana.Vol. 9, No.1, Oktober 2014.

Halim Abdul. 2013. Akuntansi Keuangan Daerah. Edisi keempat. Salemba empat. Jakarta.

Mahsun, Muhamad. 2014. Pengukuran Kinerja Sektor Publik. BPFE-Yogyakarta.

Muanley, Yonas, 2016. Berkarya Secara efektif di tahun 2017, Pengertian Efektifitas. https://teoriefektivitas.blogspot.co.id/2016/02/pengertian-efektivitas.html.

Mulyadi. 2016. Sistem Akuntansi. Salemba Empat. Jakarta

Nazir, Moh. 2014. Metode Penelitian. Bogor: Ghalia Indonesia

Republik Indonesia. 2014. Undang-Undang Nomor 23 Tahun 2014 Tentang Pemerintah Daerah.

Republik Indonesia. 2015. Undang-Undang Nomor 9 Tahun 2015 Tentang Pemerintah Daerah.

Republik Indonesia. 2004. Undang-Undang Nomor 33 Tahun 2004 Tentang Perimbangan Keuangan Antara Pemerintah Pusat dan Daerah. 
Jurnal Riset Akuntansi Going Concern 13(3), 2018, 611-617

Sujarweni, V Wiratna 2015. Akuntansi Sektor Publik. Penerbit Pustaka Baru Press. Yogyakarta.

Sugiyono. 2013. Metode Penelitian Kuantitatif, Kualitatif dan R\&D. Bandung: Alfabeta.CV 